\title{
Evaluation of Coriander (Coriandrum sativum L.) Genotypes for Yield and Quality under Hill Zone (Zone-9) of Karnataka, India
}

\author{
Akshata Hongal $^{1 *}$, N. Basavaraja ${ }^{2}$, Shivanand Hongal ${ }^{3}$, \\ N.K. Hegde ${ }^{4}$ and Sudheesh Kulkarni ${ }^{5}$ \\ ${ }^{1}$ College of Horticulture, Sirsi, 581401, India \\ ${ }^{2}$ PGS, University of Horticultural Sciences, Bagalkot - 587104, India \\ ${ }^{3}$ (VSC), College of Horticulture, Sirsi, 581401, India \\ ${ }^{4}$ Department of Horticulture, College of Horticulture, Sirsi, 581401, India \\ ${ }^{5}$ (PMA), University of Horticultural Sciences, Bagalkot - 587104, India \\ *Corresponding author
}

\section{Keywords \\ Coriander, \\ Genotype, Hill \\ zone, Rabi, Seed \\ spice}

Article Info

Accepted:

18 April 2018

Available Online:

10 May 2018

\section{A B S T R A C T}

Coriander (Coriandrum sativum L.) is an important seed spice cultivated in India. The effort was made to cultivate and evaluate the different genotypes of coriander in hill zone (Zone-9) of Karnataka. The Uttara Kannada district of Karnataka comes under Zone-9, which receives $2500-3000 \mathrm{~mm}$ rainfall annually and paddy is grown as a rainfed crop during Kharif season. After the harvest of paddy the land is kept vacant, even though there is sufficient amount of residual moisture is available. Hence, an attempt was made to introduce coriander as spice crop in hill zone of Karnataka. Identification of high yielding genotypes/varieties suitable for hill zone (Zone-9) of Karnataka is very important for improving the adoptability and productivity of the crop. Evaluation of genotypes for yield and quality will help for crop improvement programme. Hence, the present study was undertaken at College of Horticulture, Sirsi during rabi 2015 to know the performance and adaptability of promising genotypes for hill zone. Among the fifteen genotypes evaluated with respect to yield and quality, the genotypes DCC-28 (6.43 q) and DCC-36 (5.73 q) recorded maximum seed yield per hectare and the genotypes DCC-33 $(0.27 \%)$ and DCC$27(0.26 \%)$ produces higher essential oil content. These genotypes can be used successfully for further breeding programmes.

\section{Introduction}

Coriander (Coriandrum sativum L.) is an important seed spice belonging to the family Apiaceae. The plant is native to Eastern Mediterranean region and Southern Europe. It is an annual herb and is one of the most important annual seed spice produced in India and other countries like Europe, Northern
Africa, West, Central and South Asia. It is mainly used as condiment in the preparation of curry powder, pickles, sausages and seasonings. Seeds are also used in the preparation of confectionary and liquors. Due to its pleasant aroma, tender shoots and leaves are used in chutney, soups and salads. The seeds also contain essential aromatic oil. Besides condiment, coriander also has 
medicinal values. The dry seeds are said to have carminative, diuretic, stomachic and aphrodisiac properties. In India, it is cultivated in an area of 552.66 thousand hectare with the production of $461.72 \mathrm{t}$ (Anonymous, 2016). Even though India is a major producer of coriander in the world, the productivity of coriander is low. Thus, there is a great scope for crop improvement in coriander for increasing yield and quality and breeding of high yielding coriander varieties become inevitable. However India being a wast country with varied agro-climatic regions, different genotypes need to be evolved for specific regions. Hence, the present study was undertaken to evaluate different genotypes for yield and quality.

\section{Materials and Methods}

The investigation was carried out at College of Horticulture, Sirsi (Uttara Kannada), on red laterite soil during rabi season of 2015, which comes under hill zone (Zone-9) of Karnataka, located at $14^{\circ} 42.53^{\prime}$ North latitude and $74^{\circ}$ 41.58' East longitude and at an altitude of 637 $\mathrm{m}$ above the mean sea level.

In present experiment fifteen genotypes have been collected from HREC, Devihosuru, Haveri, (Table 1) were raised in Randomized Complete Block Design (RCBD) with three replications. Each genotype was raised in flat beds of $2.0 \times 2.0 \mathrm{~m}$ in size and seeds were sown at $30 \mathrm{~cm}$ line spacing. Five randomly selected plants in each genotype in each replication were tagged for recording observations on growth, yield and quality characters and the mean values were subjected to statistical analysis.

Recommended package of agronomic practices and plant protection measures were followed as per need to raise a healthy crop. Data like plant height, number of leaves, number of primary and secondary branches, plant spread, biomass production, herbage yield, days to $50 \%$ flowering, number of umbels per plant, number of umbellets per umbel, number of seeds per umbellet, days to harvest, seed yield and oil recovery were recorded on five competitive plants, while total seed yield and biomass yield were calculated on plot basis. Harvest index (HI) was estimated by following formula:

Harvest index $(\%)=\frac{\text { Economic yield }}{\text { Biological yield }}$

\section{Results and Discussion}

The observation recorded for evaluation varied significantly with respect to growth yield and quality characters are presented in Table 2 and 3.

Among the 15 genotypes evaluated during rabi season, DCC-36 recorded highest plant height $(45.67 \mathrm{~cm})$. The genotype DCC-37 $(41.97 \mathrm{~cm})$ was next in the order and the lowest was observed in DCC-40 $(28.53 \mathrm{~cm})$ at 60 DAS. These variations were attributed to genetic makeup of the genotypes and its interaction with the environmental variations in season. There are several reports indicating variation in plant height among the genotypes and varieties under different agro-climatic conditions. Of the 15 coriander genotypes evaluated, the number of leaves per plant was maximum in genotypes DCC-28, DCC-39 and DCC-33 (15.33, 14.93 and 14.23 respectively). The minimum number was observed in DCC-38 (11.67), which shows the good amount of variation exists among the genotypes studied. Such variation in leaf number among the different varieties of seed spices were also reported by several workers in coriander, Datta et al., (2001), Patil (2003), Velayudham (2004), Giridhar and Sarada (2005), Chaulagain et al., (2011), Palanikumar and Rajamani (2012), Malik and Tehlan 
(2013) and Moniruzzaman et al., (2013). The number of primary branches per plant varied from 7.33 (DCC-34) to 5.13 (DCC-29), while it was seen from the results that significantly higher primary branches were produced by genotypes DCC-34, DCC-30 and DCD-26 (7.33, 6.67 and 6.50, respectively) and least was observed in DCC-29 (5.13). These variations could be due to genetic character of genotype and environmental influence. Number of secondary branches varied from 12.17 (DCC-26) to 6.00 (DCC-38 and DCC39). The highest number of secondary branches was observed in DCC-26 (12.17). The genotype DCC-40 (10.23) was next in order and the least was observed in DCC-38 and DCC-39 (6.00). These variations in primary and secondary branches may be due to its genetic characters and due to interaction with environment. There are several reports indicating variation with respect to number of secondary branches by several workers in coriander, Hariprasadrao and Srinivasrao (2001), Selvarajan et al., (2002) and Saxena et al., (2005).

Plant spread in E-W differed significantly in different coriander genotypes. In rabi, the highest E-W plant spread was observed in DCC-34, DCC-35 and DCC-36 (16.77 cm, $15.92 \mathrm{~cm}$ and $15.33 \mathrm{~cm}$ respectively) and the lowest was recorded in DCC-31 $(6.80 \mathrm{~cm})$. The maximum N-S plant spread was observed in DCC-36 (17.10 cm) and DCC-28 (15.53 $\mathrm{cm})$ was in the next order. The minimum was recorded in DCC-32 $(8.03 \mathrm{~cm})$. These variations may be due to the increase in plant height and number of branches per plant.

The present study revealed that the biomass production differed significantly among the genotypes evaluated. The highest biomass production was observed in DCC-35, DCC28, DCC-30 and DCC-34 (7.21 g, $6.57 \mathrm{~g}, 6.45$ $\mathrm{g}$ and $6.40 \mathrm{~g}$ respectively) and the lowest was recorded in DCC-27 (2.98 g). Similar variations observed in biomass production among the different varieties were reported by several workers in coriander, Datta et al., (2001), Patil (2003), Palanikumar and Rajamani (2012) and Malik and Tehlan (2013).

Days to $50 \%$ flowering are an important trait in selection for earliness in Crop improvement programme. Coriander genotypes showed differences in relation to days to 50 per cent flowering in the present study. The DCC-35 took less number of days for flowering (42.33 days) and it was more in DCC-39 (50.00 days), followed by DCC-30 (43.00 days) and DCC-29 (42.67 days). This differential performance of genotypes could be attributed to difference in environment and variation in their intrinsic properties and crop genotype cultivated in the region of production may be less adapted than its adopted region, where it is usually produced. Similar variations for days to flowering are also reported by several workers in coriander, Subramanian et al., (2005), Vashishtha and Malhotra (2005), Bhattacharya et al., (2006), Prabhu and Balakrishnamurthy (2006) and Dhokle et al., (2009).

As coriander is a dual purpose crop, herbage yield is also one of the important traits in selecting the high yielding genotypes.

A comparison of coriander genotypes indicated significant differences among the genotypes in relation to herbage yield. The genotype DCC-34 recorded higher herbage yield $(6.26 \mathrm{~g})$ followed by DCC-29 (5.15 g) and DCC-28 (5.12 g). There are several reports indicating variation in herbage yield among the coriander genotypes and varieties from different agro-climatic conditions by several workers, Giridhar and Sarada (2005), Chaulagain et al., (2011), Palanikumar and Rajamani (2012) and Malik and Tehlan (2013). 
Table.1 Genotypes used for evaluation

\begin{tabular}{|c|c|c|}
\hline SI. No & Genotype & Source of collection \\
\hline 1 & $\begin{array}{c}\text { DCC-26 (Devihosur } \\
\text { Coriander Collection-26) }\end{array}$ & $\begin{array}{l}\text { Horticulture research and extension centre, Devihosuru } \\
\qquad \text { (HREC, Devihosuru), Haveri. }\end{array}$ \\
\hline 2 & DCC-27 & HREC, Devihosuru, Haveri. \\
\hline 3 & DCC-28 & HREC, Devihosuru, Haveri. \\
\hline 4 & DCC-29 & HREC, Devihosuru, Haveri. \\
\hline 5 & DCC-30 & HREC, Devihosuru, Haveri. \\
\hline 6 & DCC-31 & HREC, Devihosuru, Haveri. \\
\hline 7 & DCC-32 & HREC, Devihosuru, Haveri. \\
\hline 8 & DCC-33 & HREC, Devihosuru, Haveri. \\
\hline 9 & DCC-34 & HREC, Devihosuru, Haveri. \\
\hline 10 & DCC-35 & HREC, Devihosuru, Haveri. \\
\hline 11 & DCC-36 & HREC, Devihosuru, Haveri. \\
\hline 12 & DCC-37 & HREC, Devihosuru, Haveri. \\
\hline 13 & DCC-38 & HREC, Devihosuru, Haveri. \\
\hline 14 & DCC-39 & HREC, Devihosuru, Haveri. \\
\hline 15 & DCC -40 & HREC, Devihosuru, Haveri. \\
\hline
\end{tabular}


Table.2 Performance of coriander genotypes for different growth parameters

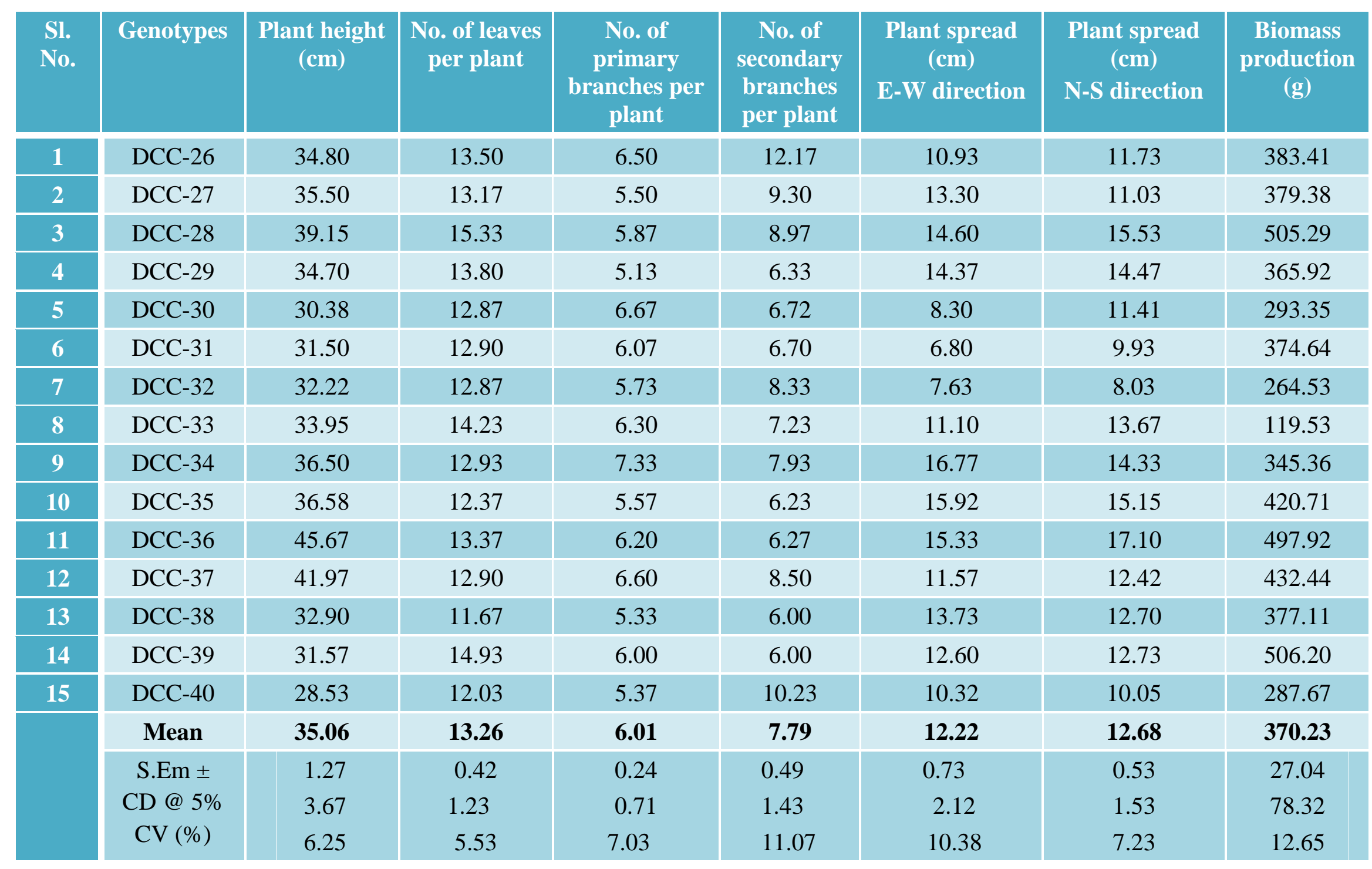


Table.3 Yield and quality parameters in different coriander genotypes

\begin{tabular}{|c|c|c|c|c|c|c|c|c|c|c|c|}
\hline $\begin{array}{l}\text { Sl. } \\
\text { No. }\end{array}$ & Genotypes & $\begin{array}{c}\text { Days to } 50 \\
\text { per cent } \\
\text { flowering }\end{array}$ & $\begin{array}{l}\text { Herbage } \\
\text { yield (g) }\end{array}$ & $\begin{array}{c}\text { No. of } \\
\text { umbels per } \\
\text { plant }\end{array}$ & $\begin{array}{c}\text { No. of } \\
\text { umbellets } \\
\text { per umbel }\end{array}$ & $\begin{array}{l}\text { No. of } \\
\text { seeds per } \\
\text { umbellets }\end{array}$ & $\begin{array}{l}\text { Days to } \\
\text { harvest }\end{array}$ & $\begin{array}{c}\text { Test weight } \\
\text { (g) }\end{array}$ & $\begin{array}{l}\text { Seed yield } \\
\text { (q/ha) }\end{array}$ & $\begin{array}{l}\text { Harvest } \\
\text { index }(\%)\end{array}$ & $\begin{array}{c}\text { Essential } \\
\text { oil content } \\
(\%)\end{array}$ \\
\hline 1 & DCC-26 & 46.67 & 413.15 & 12.53 & 4.08 & 6.43 & 90.00 & 0.70 & 4.41 & 50.24 & 0.23 \\
\hline 2 & DCC-27 & 45.33 & 404.65 & 11.77 & 3.60 & 6.47 & 88.00 & 0.68 & 4.26 & 56.33 & 0.26 \\
\hline 3 & DCC-28 & 47.00 & 480.80 & 18.03 & 6.35 & 7.93 & 87.67 & 0.81 & 6.43 & 42.71 & 0.22 \\
\hline 4 & DCC-29 & 42.67 & 369.90 & 16.33 & 4.84 & 7.50 & 86.33 & 0.74 & 5.23 & 49.80 & 0.22 \\
\hline 5 & DCC-30 & 43.00 & 397.00 & 13.50 & 3.64 & 5.50 & 86.67 & 0.65 & 4.18 & 44.56 & 0.06 \\
\hline 6 & DCC-31 & 44.00 & 417.35 & 11.17 & 3.41 & 6.33 & 86.33 & 0.77 & 4.11 & 43.14 & 0.16 \\
\hline 7 & DCC-32 & 47.67 & 365.25 & 10.33 & 4.43 & 7.00 & 87.67 & 0.77 & 3.54 & 49.45 & 0.20 \\
\hline 8 & DCC-33 & 47.33 & 415.95 & 14.33 & 4.30 & 7.00 & 86.67 & 0.59 & 2.72 & 46.29 & 0.27 \\
\hline 9 & DCC-34 & 43.33 & 588.00 & 15.70 & 4.60 & 6.69 & 87.00 & 0.73 & 2.77 & 43.75 & 0.12 \\
\hline 10 & DCC-35 & 42.33 & 424.00 & 14.57 & 3.82 & 6.17 & 86.00 & 0.69 & 3.99 & 38.33 & 0.22 \\
\hline 12 & DCC-37 & 46.67 & 376.95 & 9.37 & 3.33 & 5.07 & 86.33 & 0.58 & 2.45 & 34.63 & 0.25 \\
\hline 13 & DCC-38 & 44.33 & 365.25 & 13.60 & 3.99 & 6.43 & 87.00 & 0.56 & 3.16 & 47.64 & 0.13 \\
\hline 14 & DCC-39 & 50.00 & 391.96 & 9.67 & 4.56 & 7.17 & 89.00 & 0.65 & 3.93 & 49.33 & 0.21 \\
\hline 15 & DCC -40 & 46.67 & 423.05 & 12.67 & 3.89 & 5.51 & 87.00 & 0.69 & 3.79 & 56.67 & 0.16 \\
\hline & Mean & 45.47 & 417.80 & 13.36 & 4.27 & 6.59 & 87.18 & 0.69 & 4.05 & 46.32 & 0.19 \\
\hline & \multirow{3}{*}{$\begin{array}{c}\text { S.Em } \pm \\
\text { CD @ 5\% } \\
\text { CV }(\%)\end{array}$} & 0.92 & 23.20 & 0.70 & 0.30 & 0.33 & 0.52 & 0.04 & 0.30 & 2.92 & 0.003 \\
\hline & & 2.66 & 67.21 & 2.03 & 0.86 & 0.96 & 1.52 & 0.11 & 0.88 & 8.46 & 0.010 \\
\hline & & 3.50 & 9.62 & 9.08 & 12.09 & 8.70 & 1.04 & 9.36 & 12.96 & 10.92 & 4.53 \\
\hline
\end{tabular}


The factors mainly responsible for the differences in the seed yield among the genotypes are due to the differences in the yield attributes like umbels per plant, umbellets per umbel, seeds per umbellet and test weight. These differences in the yield components could be further attributed to the variability in the growth parameters. In the present study, higher yield was observed in DCC-28, DCC-36 and DCC-29. It was attributed to the production of more number of umbels per plant, umbellets per umbel, seeds per umbellet and higher test weight. The higher seed yield was recorded in DCC28 (6.28 q/ha). Similarly, DCC-37 failed to record high yield due to its smaller seeds with the lower test weight $(0.58 \mathrm{~g})$.

Among the yield components, number of seeds per umbellet seems to be the most important and closely associated component with seed yield per plant. High yielding ability in genotypes could be attributed to significantly higher number of seeds per umbellet. The genotypes DCC-28, DCC-36 and DCC-29 produced more seeds per umbellet (7.93, 7.70 and 7.50, respectively) as compared to DCC-37 (5.07). In the present investigation, apart from seeds per umbellet, umbels per plant, umbellets per umbel also differed significantly among genotypes. The higher umbels per plant were recorded in DCC-28 (18.03), DCC-36 (16.83), and DCC29 (16.33).

The seed yield is the most important character, as the genotype with higher seed yield is selected for the breeding programme and also having lot of commercial value for spice purpose. Among the 15 genotypes tested, DCC-28 recorded the highest seed yield per plant $(6.28 \mathrm{~g})$, per plot $(256.71 \mathrm{~g})$ and per hectare $(6.43 \mathrm{q})$, which was followed by DCC-36 (5.73 q/ha). The lowest was recorded in DCC-37 (2.45 q/ha). Considerable variations in the seed yield among the genotypes and varieties of coriander were also reported earlier by several workers in coriander, Datta et al., (2001), Patil (2003), Velayudham (2004), Giridhar and Sarada (2005), Chaulagain et al., (2011), Palanikumar and Rajamani (2012), Malik and Tehlan (2013) and Moniruzzaman et al., (2013).

Data on the seed oil content revealed significant variation among the genotypes evaluated and ranged from 0.06 to 0.27 per cent. Among the 15 genotypes evaluated, DCC-33 (0.27\%) and DCC-27 (0.26\%) were found to possess higher seed oil content than other genotypes and the lowest oil content was found in DCC-30 $(0.06 \%)$. There are several reports indicating variation in seed oil content among the coriander genotypes and varieties tested in different agro-climatic conditions by several workers in coriander, Hariprasadrao and Srinivasrao (2001), Selvarajan et al., (2002), Patil (2003), Velayudham (2004), Giridhar and Sarada (2005), Vashishtha and Malhotra (2005), Prabhu and Balakrishnamurthy (2006), Dhokle et al., (2009), Chaulagain et al., (2011), Palanikumar and Rajamani (2012), Malik and Tehlan (2013) and Moniruzzaman et al., (2013).

As days to harvest indicate the earliness of the genotype/variety, it can be used in selection of early genotype/variety. The number of days to harvest ranged from 86.00 to 90.00 days. Least number of days taken for harvest was noticed in DCC-35 and DCC-36 (86.00 days) as against highest days taken for harvest was recorded in DCC-26 (90.00 days).

Harvest index could be used as a measure of reproductive efficiency and it is used to quantify the crop species versus the total amount of biomass that has been produced. In present study the harvest index differed significantly among coriander genotypes 
evaluated. The highest harvest index was observed in DCC-40 (56.67 \%) and the lowest was found in DCC-37 (34.63\%). Similar variation in harvest index among the varieties was reported by several workers in coriander, Datta et al., (2001), Patil (2003), Velayudham (2004), Giridhar and Sarada (2005), Chaulagain et al., (2011), Palanikumar and Rajamani (2012), Malik and Tehlan (2013) and Moniruzzaman et al., (2013).

The study revealed that among the 15 different genotypes of coriander evaluated the genotypes DCC-34 and DCC-28 recorded maximum herbage yield. The genotypes DCC-28, DCC-36 and DCC-29 were found to perform well with reference to seed yield and the genotypes DCC-33 and DCC-27 were found to give higher essential oil content under hill zone (Zone-9) of Karnataka. These genotypes can be used for further breeding programme.

\section{References}

Anonymous, 2016, Spices Statistics at a glance. Directorate of Arecanut and Spices Development, Calicut, Kerala, India. pp156.

Bhattacharya, M., Chatterjee, R., Pan S., Sharangi, A. B. and Pariari, A., 2006, Growth and yield of different cultivars of fenugreek (Trigonella foenumgraecum L.) as influenced by dates of sowing. The Orissa J. Hort., 34(1): 6971.

Chaulagain, R., Pant, S. S., Thapa, R. B. and Sharma, M. D., 2011, Performance of coriander cultivars for green leaf production under late sowing condition. The J. Agri. and Env., 12: 67-73.

Datta, S., Chatterjee, R., Medda, P. S. and Chattopadhyay, P. K., 2001, Evaluation of ajowan (Trachyspermum ammi L.). Introductions for growth, yield and quality. J. Spices and Arom. Crops, 10(1): 37-39.

Dhokle, G. C., Naik, P. G., Suryawanshi, A. B. and Phad, G. N., 2009, Performance of different varieties of coriander for yield, quality and germination under Marathwada conditions. The Asian J. Hort., 4(2): 355-357

Giridhar, K. and Sarada, C., 2005, Identification of coriander (Coriandrun sativum L.) genotypes of vertisols of Andhra Pradesh. Nat. Symp. Cur. Trends in Onion, Gralic, Chillies and Seed Spices - Production, Marketing and Utilization, SYMSAC-II, 25-27 November, NRCOG, Rajgurunagar, pp. 92.

Hariprasadrao, N. and Srinivasarao, G., 2001, Studies on the performance of exotic and indigenous coriander (Coriandrum sativum L.) genotypes for greens. The Andhra Agril. J., 48(3-4): 324-326.

Malik, T. P. and Tehlan S. K, 2013, Performance of coriander (Coriandrum sativum L.) varieties for growth and seed yield. Int. J. Seed Spices, 3(2): 8990.

Moniruzzaman, M., Rahman, M. M., Hossain, M. M., Sirajul Karim, A. J. M. and Khalig, Q. A., 2013, Evaluation of coriander (Coriandrum sativum L.) genotypes for seed yield and yield contributing characters. Bangladesh J. Agril. Res., 38(2): 189-202.

Palanikumar, M. and Rajamani, K., 2012, Evaluation of coriander genotypes for fresh, dry biomass yield and oil content under different seasons. Crop Res., 44(1\&2): 194-202.

Patil, P. B., 2003, Evaluation of fenugreek (Trigonella foenum-graecum L.) genotypes. M.Sc. (Hort.) Thesis, Univ. Agric. Sci., Dharwad.

Prabhu, T. and Balakrishnamoorthy, G., 2006, Evaluation of coriander (Coriandrum sativum L.) accessions under irrigated 
conditions for growth, yield and quality. Proc. Nat. Sem. Emerging Trends in Production, Quality, Processing and Export of Spice, 28- 29 March, Coimbatore, p. 13.

Saxena, R. P., Pandey, V. P., Datta, J. and Gupta, R. K., 2005, Performance of coriander entries at Kumarganj, Faizabad. Nat. Symp. Cur. Trends in Onion, Garlic, Chillies and Seed Spices - Production and Utilization, SYMSAC-II, 25-27 November, NRCOG, Rajgurunagar, pp. 55-56.

Selvarajan, M., Chezhiyan, N., Muthulakshmi, P. and Ramar, A., 2002, Evaluation of coriander genotypes for growth and yield. South Indian Hort., 50(4-6): 458-462.
Subramanian S. Rajeswari E. and Chezhiyan N., 2005, Screening of coriander genotypes for yield, quality and powdery mildew. South Indian Hort., 53(1-6): 168-171.

Vashisththa and Malhotra, 2005, Crop improvement on seed spices. Nat. Symp. Cur. Trends in Onion, Garlic, Chillies and Seed Spices-Production, Marketing and Utilization, SYMSACII, 25-27 November, NRCOG, Rajgurunagar, pp. 30-36.

Velayudham, A., 2004, Evaluation and effects of organics with bio-inoculants in coriander var. C0-3. M.Sc. (Hort.) Thesis, Univ. Agric. Sci., Dharwad.

\section{How to cite this article:}

Akshata Hongal, N. Basavaraja, Shivanand Hongal, N.K. Hegde and Sudheesh Kulkarni. 2018. Evaluation of Coriander (Coriandrum sativum L.) Genotypes for Yield and Quality under Hill Zone (Zone-9) of Karnataka, India. Int.J.Curr.Microbiol.App.Sci. 7(05): 2494-2502. doi: https://doi.org/10.20546/ijcmas.2018.705.287 